\title{
In Vitro Antibacterial Activity of Rumex nervosus and Clematis simensis Plants Against Some Bacterial Human Pathogens
}

\author{
Habtamu Tedila* Addisu Assefa \\ College of Natural and Computational Science Department of Biology (Stream of Applied Microbiology), \\ Madda Walabu University, PO box 247, Bale Robe, Ethiopia
}

\begin{abstract}
Due to quick growth of resistance and high cost of new generation antibiotics, lots of efforts were made to discover new antimicrobial agents from various sources. So, current study was assessed antibacterial activity of ethanol, methanol, acetone, diethyl ether and hexane leave extracts of Rumex nervosus and Clematis simensis by used paper disc diffusion and broth dilution procedures against six human pathogenic bacterial strains. The pathogenic bacteria were Shigella dysenteriae, Escherichia coli, Staphylococcus aureus, Pseudomonas aeruginosa, Salmonella typhi and Klebsiella pneumoniae were susceptible to ethanol, methanol and acetone extracts of the leaves of Rumex nervosus followed by Clematis simensis, but hexane extract didn't displayed any activity. The extreme inhibition zone of $16.3 \pm 0.57 \mathrm{~mm}$ was detected against $E$ coli by ethanol extract of Rumex nervosus and MIC of $3.125 \mathrm{mg} / \mathrm{ml}$ against Escherichia coli and Shigella dysenteriae by methanol extract. The methanol extract of Clematis simensis formed a marked inhibition of $13.1 \pm 0.37$ mm against Escherichia coli and ethanol extract of Clematis simensis displayed activity against Shigella dysenteriae $14.4 \pm 0.45 \mathrm{~mm}$ and MIC of $6.25 \mathrm{mg} / \mathrm{ml}$ against Salmonella typhi. Four dissimilar antibiotics like Ciprofloxin, Tetracyclin, Kanamycin and Chloramphenicol were used as standard for tested antibacterial activity against six different human pathogens. The activities were recognized the presence of some secondary metabolites existed in the tested floras which have related with antibacterial activities.
\end{abstract}

Keywords: Antibacterial activity, Clematis simensis, Human pathogens, Rumex nervosus

DOI: $10.7176 /$ ALST/72-02

Publication date:March $31^{\text {st }} 2019$

\section{Introduction}

Traditional medicine is a popular form therapy in developing countries and its use broadly recognized in numerous literatures. The improving emergence of antimicrobial resistance deteriorates the impact (Mulu et al., 2006; Olivier et al., 2010). It has been shown that risk of negative clinical consequences, mortality, and high treatment costs with drug-resistant bacteria is generally higher compared to patients infected with the same nonresistant bacteria (WHO 2003). Improved prevalence of resistant bacteria, together with lack and high cost of new generation drugs has escalated infection-related morbidity and mortality particularly in developing countries like Ethiopia (Mulu et al., 2006; Borkotoky et al., 2013). This proliferation endorsed to undifferentiating use of broad-spectrum antibiotics, immunosuppressive agent, intravenous catheters and ongoing epidemics of HIV infection (Dean and Burchard 1996; Gonzalez et al., 1996). However, the progress of new antibiotics should continue as the primary significance to retain the usefulness of antimicrobial treatment (Marchese and Shito 2001). The potential of floras are bases for modern medicine to achieve new values (Evans et al., 2002).

In recent years, pharmacological enterprises consumed a lot of time and money in developing natural products extracted from plants, to harvest extra cost real medicines that are reasonable to the population (Doughari 2006). Today, many commercially confirmed drugs used in modern medicine were firstly used in crude form in traditional or folk healing performs, or for other purposes that suggested potentially useful biological activity. The therapeutic floras around the world contain various compounds with antibacterial activity (Marjorie 1999). So, orderly screening them may result in the detection of novel real antimicrobial compounds (Costa et al., 2008). The screening of plant extracts and plant products for antimicrobial activity has shown that floras represent a potential source of new anti-infective agents (Amani et al., 1998; Costa et al., 2008). Many researches have carried out to screen natural products for antimicrobial property (Nair and Chanda 2006). Therapeutic floras possess immune modulatory and antioxidant properties, leading to antibacterial activities. They have versatile immune modulatory activity by stimulating both non-specific and specific immunity (Pandey and Chowdhry 2006).

Rumex nervosus mostly originated high altitude areas (above 1000m) and continue about 200 species. The leaves of this plant are edibles in Ethiopia. In Ethiopia, the leaves and stem of this herb are used for purifying the body by women traditionally as substituent of olive tree, to do this, the leaves are put on fire then they cover the patient body with that hot leaves and blanket so that the vapors and smoke surround all the body (Madhu et al ., 2014). Rumex species contains anthrax derivatives like chrysophanol, physician, emodin, aloe-emodin, rhein; which are the main biologically active compounds responsible for anti-cancer, cytotoxic, genotoxic and mutagenicity properties (Wegiera et al., 2012). Traditionally in Ethiopia, the leaves, stems and roots of Rumex 
nervosus were used as traditional medicines, for the eye disease, taeniacapitis, hemorrhoids, infected wounds, arthritis, eczema, abscess and gynecological disorders.

Clematis simensis is woody climber that escalates up to $10 \mathrm{~m}$ or more, occasionally with long branches lying on the ground. The stem is pubescent; leaves are pinnate while the leaflets are ovate. The superior of the leaves have disseminated hairs while the inferior one is to Mentos. The inflorescence was various flowered, the flowers being pale yellow to white in color (Edwards et al., 2000). Traditionally in Ethiopian the plants leaves were used for dress wounds and also for the treatment of eczema, tinea capitis and tropical ulcers and also the seeds of this plant were used for rheumatic pain while the sap was used as a febrifuge and against bloat in animals. A recent study reported that the leaves of $C$. simensis used in combination with another plant from the same family (Addis et al., 2001; Gedif et al., 2001). Traditionally plants used for the treatment of gonorrhea, syphilis and sore throat. The leaves have also been used for the treatment of leprosy, fever and various skin diseases and headaches (Iwu, 1993; Kakwaro, 1976). The extracts leaves of $C$. simensis by aqueous and methanol are exhibit activity against certain bacteria like Staphylococcus aureus, Pseudomonas aeruginosa and fungi Candida albicans (Desta et al., 1993; Cos et al., 2002).

In Ethiopia, medicinal plants are still the most important and occasionally the only bases of therapeutics for nearly $80 \%$ of human and more than $90 \%$ in livestock population. Estimated floras of 6,500 to 7,000 species of higher plants are originated in Ethiopia and about $12 \%$ are endemic to the country (Tadeg et al., 2005). Despite their vital role in providing for the health of human and livestock population, large part of the knowledge of ethno medicinal plants is irreversible loss and declining to deterioration due the oral passage of herbal heritage from generation to generation rather than in writings (Mesfin et al., 2009). Ecological degradation, farming growths, cultivation of marginal lands and suburbanization are also posing a significant threat to the future wellbeing of human and animal populations that have relied on these resources to fight several ailments for generations (Lulekal et al., 2008: Devi et al., 2009).

\section{Materials and Methodology}

\subsection{Location of the study area}

The study was conducted on selected medicinal plants composed from Sinana and Agarfa districts of Bale zone, Oromia Regional State, South Eastern Ethiopia. Sinana district was found at $430 \mathrm{~km}$ southeast of Addis Ababa. The area was situated at $7^{\mathrm{O}} 7^{\prime} \mathrm{N}$ and $40^{\circ} 10^{\prime} \mathrm{E}$ and 2,400 masl. The mean average rainfall of the area was 353 $\mathrm{mm}$. For the same period, average annual maximum temperature was $21.2^{\circ} \mathrm{C}$ and minimum temperature was $9.4^{\circ} \mathrm{C}$. The dominant soil type was pellic vertisol and slightly acidic $(\mathrm{pH}=6)$. Agricultural production system of the study area was mixed farming. Agarfa district was located at $464 \mathrm{~km}$ south east of Addis Ababa. The area was situated at $6^{\circ} 11^{\prime} \mathrm{N}$ and $40^{\circ} 3^{\prime} \mathrm{E}$ and 2,350 masl. The mean average rainfall of the area was $880 \mathrm{~mm}$ and bimodal. The average annual maximum temperature was $24.75^{\circ} \mathrm{C}$ and minimum temperature was $7.1^{\circ} \mathrm{C}$. The dominant soil type was clay soil and slightly acidic $(\mathrm{pH}=5.8)$. Agricultural production system of the study area was mixed farming.

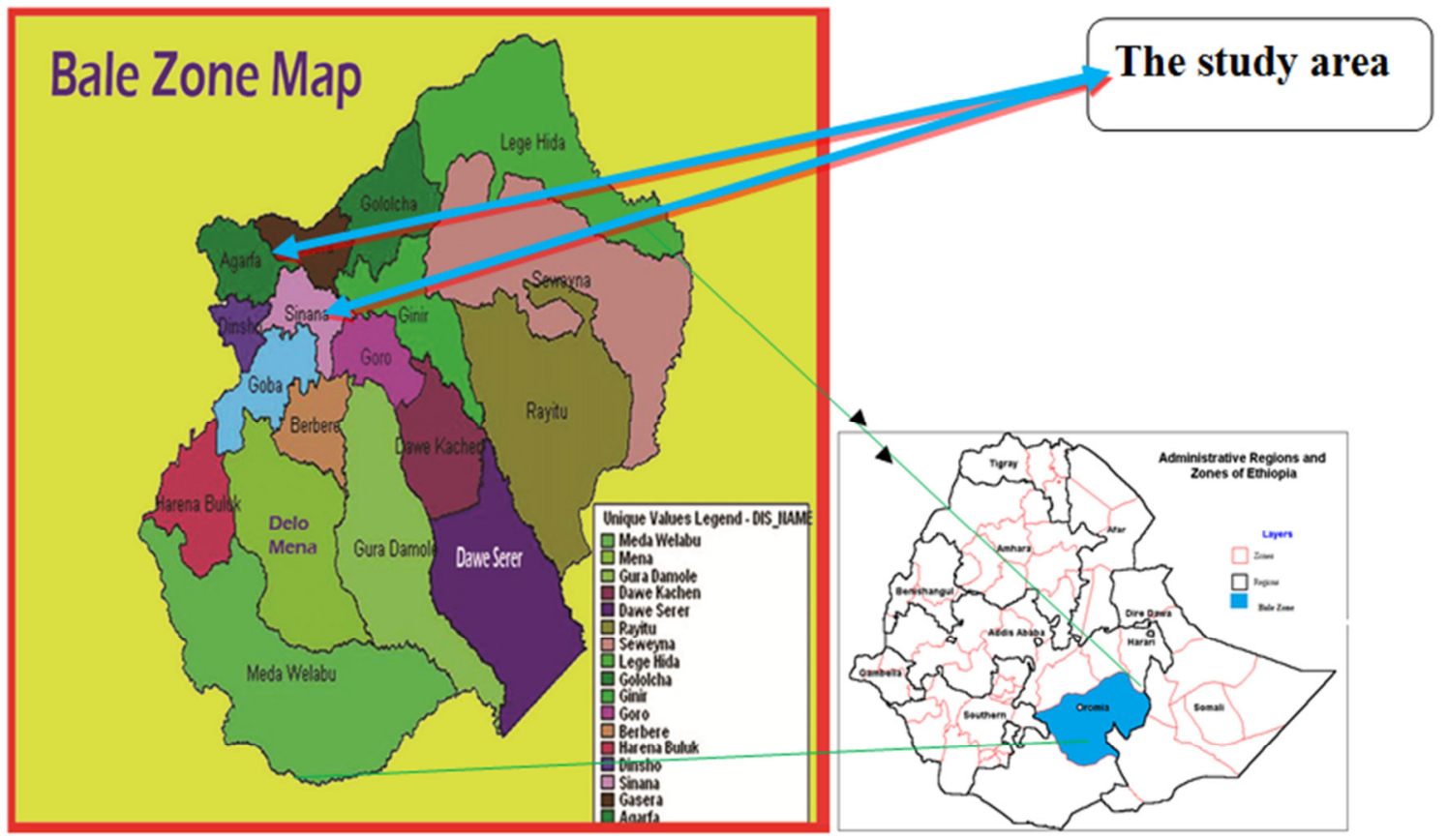

Figure 1 Map of study area 


\subsection{Collection and identification of plant materials}

Two medicinal plants Rumex nervosus and Clematis simensis were collected from Bale Zone, Sinana and Agarfa district Oromia region, Ethiopia. The taxonomic situation of the plants was identified and authenticated by plant experts from National Herbarium in Addis Ababa University. Leaves from the study plants were taken in a large quantity and repeatedly washed under tap water to remove any debris and were air dried under shade for fifteen days.

\subsection{Preparation of plant's crude extracts}

The preparation of crude extracts of plants under this study was conducted followed the methods used by Tadeg and coll. (2005) used different solvents. Five hundred grams of leaves from each plant was taken for extraction procedure and ground in a mortar and pestle separately under aseptic condition. Twenty grams of each powdered plant material were extracted with apparatus with $250 \mathrm{ml}$ of ethanol, methanol, diethyl ether, hexane and acetone separately by maceration for $48 \mathrm{~h}$ with frequent agitation on orbital shaker for continuous two days and the resulted liquid was filtered (Whatman No. 3 filter paper, Whatman Ltd., England). Extraction was repeated five times and the filtrates of all portions were combined in one vessel. The organic solvent was removed by evaporation used Rota vapor (BU“'CHI Rota-vapor R-205, Switzerland) at $40^{\circ} \mathrm{C}$. The resulted dehydrated mass was then crushed, packed into a glass vial until used. Finally, the gram yield of dried residue of each plant extracts were calculated. The concentrated extracts were stored at $4^{\circ} \mathrm{C}$ for the next antimicrobial study. Dried residues were dissolved in $100 \%$ dimethyl sulfoxide (DMSO) to obtain a stock concentration of $100 \mathrm{mg} / \mathrm{ml}$, which was kept at $4{ }^{\circ} \mathrm{C}$ until used.

\subsection{Preparation of tested microorganisms}

The tested microorganisms included Escherichia coli, Salmonella typhi, Shigella dysenteriae, Pseudomonas aeruginosa, Staphylococcus aureus and Klebsiella pneumoniae were obtained from Ethiopian Public Health Institute (EPHI), Addis Ababa, Ethiopia. These microorganisms were suspended in nutrient broth and subcultured into fresh nutrient agar medium and kept at $4{ }^{\circ} \mathrm{C}$ until used. The inoculated preparation was standardized by inoculated bacterial strains from the exponential phase and standardized with $0.5 \mathrm{McFarland}$ turbidity standard prepared by added a $0.5 \mathrm{~mL}$ aliquot of $1.175 \% \mathrm{w} / \mathrm{v} \mathrm{BaCl}{ }_{2} .2 \mathrm{H}_{2} \mathrm{O}$, added to $99.5 \mathrm{~mL}$ of 0.18 $\mathrm{mol} / \mathrm{L} \mathrm{H}_{2} \mathrm{SO}_{4}(1 \% \mathrm{v} / \mathrm{v})$.

\subsection{Antimicrobial Assay}

\subsubsection{Antibacterial sensitivity tested used disc diffusion method}

The antibiotic susceptibility tested, stock concentrations of $(100 \mathrm{mg} / \mathrm{ml})$ plant crude extracts were prepared in DMSO. A circular antibiotic assay disc of $6 \mathrm{~mm}$ diameter was prepared from the Whatman filter paper No.3 and sterilized by autoclave for $15 \mathrm{~min}$ at $121^{\circ} \mathrm{C}$. The sterile discs were impregnated with $50 \mu \mathrm{l}$ of the reconstructed extract and were dried completely at $37{ }^{\circ} \mathrm{C}$ overnight. A sterile cotton swab was dipped into a homogenous suspension of tested microorganism with adjusted $0.5 \mathrm{McFarland}$ turbidity standards. The tested pathogenic microorganisms were swabbed gently by cotton swab onto Muller Hinton Agar (MHA) and were then allowed to dry for half an hour. The discs were aseptically placed over plates of Muller Hinton Agar (MHA) (Haniyeh et al., 2010). The plates were incubated in an upright position at $37^{\circ} \mathrm{C}$ for 24 hours and the zone of inhibition was measured (in $\mathrm{mm}$ diameter). Inhibition zones with diameter less than $12 \mathrm{~mm}$ was considered as had low antibacterial activity. Diameters between 12 and $16 \mathrm{~mm}$ was considered moderately active, and these with $>16 \mathrm{~mm}$ was considered highly active (Indu et al., 2006). The tested microorganisms were tested for their sensitivity against the standard antibiotics, Ciprofloxacin $(35 \mu \mathrm{g})$, Chloramphenicol $(30 \mu \mathrm{g})$ Tetracycline $(30 \mu \mathrm{g})$ and Kanamycin $(20 \mu \mathrm{g})$ by the disc diffusion method (Bauer et al., 1966).

\subsubsection{Minimum Inhibitory Concentration (MIC) assay methods}

The minimum inhibitory concentration (MIC) was determined by compared the various concentrations of plant extracts which have different inhibitory effect and selected the lowest concentration of extract showed inhibition (Agatemor, 2009). The minimum inhibitory concentration (MIC) was determined for extracts that showed inhibition zone of $\geq 7 \mathrm{~mm}$ diameter and for extract that inhibited the growth of all tested bacteria at concentration of $200 \mathrm{mg} / \mathrm{ml}$. The tested was performed by used standard tube dilution (serial dilution) method used nutrient broth as diluents. Accordingly, the plant extract was prepared by double serial dilution from 200 $\mathrm{mg} / \mathrm{ml}$ to obtain $1: 2,1: 4,1: 8,1: 16,1: 32$, and $1: 64$ in order to get $100,50,25,12.5,6.25,3.125,1.56$ and 0.78 $\mathrm{mg} / \mathrm{ml}$ concentration of extract respectively using 50\% DMSO. $1 \mathrm{ml}$ of each extracts was dissolved in sterile test tubes which contained $9 \mathrm{ml}$ of nutrient broth. Then, $0.1 \mathrm{ml}$ of the tested microorganism was inoculated to the each tube. One tube was used as the control (broth + extract). The tubes were incubated at $37^{\circ} \mathrm{C}$ for $24 \mathrm{~h}$ and the existence of growth was assessed by compared the optical density (OD) of each well before and after incubation. When the difference of OD value (after incubation-before incubation) of the test (broth + extract + organism) was greater than that of the control (broth + extract) at each concentration, it was considered as presence of 
turbidity or growth of bacteria. The lowest concentration, at which there was no turbidity, was also regarded as MIC value of the extract.

\subsection{Data Analysis}

Data on mean inhibition zone formed by each plant extract and MIC on various bacteria were entered in to Microsoft excels spreadsheet and SPSS (Statistical Package Software for Social Science version 16). Values were given as mean $\pm \mathrm{SD}$.

\section{Results}

\subsection{Antibacterial activity of the plant extracts}

The crude extracts study plant such as Rumex nervosus and Clematis simensis were tested for antibacterial activity on six human pathogens. The solvents that were used in this study produced an overall yield of plant crude extracts that were ranging from 0.6 to 2.4 gm from different plants (Table.1).

In-vitro antimicrobial activity of crude extracts of plants under this study was evaluated against human pathogenic bacteria of Escherichia coli, Salmonella typhi, Shigella dysenteriae, Pseudomonas aeruginosa, Staphylococcus aureus and Klebsiella pneumoniae. The results obtained in the present study revealed that the tested two medicinal plants (Rumex nervosus and Clematis simensis) extracts possess a potential antibacterial activity.

Table 1: The yield of plant crude extracts by using different solvents

\begin{tabular}{|l|l|l|l|}
\hline Plant species & Parts used $(\mathrm{gm})$ & Extraction type & Yield in grams (Mean in mm) \\
\hline \multirow{3}{*}{ Rumex nervosus } & \multirow{4}{*}{$(20 \mathrm{gm})$ Leaves } & Methanol & 1.6 \\
\cline { 3 - 4 } & & Ethanol & 1.35 \\
\cline { 3 - 4 } & & Diethyl ether & 0.6 \\
\cline { 3 - 4 } & & Acetone & 1.6 \\
\cline { 3 - 4 } & & Hexane & 1 \\
\hline \multirow{4}{*}{ Clematis simensis } & Methanol & 2 \\
\cline { 3 - 4 } & Ethanol & 2.4 \\
\cline { 3 - 4 } & \multirow{4}{*}{$(20 \mathrm{gm})$ Leaves } & Diethyl ether & 1.3 \\
\hline & & Acetone & 2.1 \\
\hline & & Hexane & 1.2 \\
\hline
\end{tabular}

\subsubsection{The antibacterial activity of Rumex nervosus crude extracts}

The antibacterial activity of Rumex nervosus crude extracts was assayed by disc diffusion method. The methanol and ethanol leaves extract of Rumex nervosus showed considerably a higher mean antibacterial activity as compared to other solvents. The highest antibacterial activity was exhibited on Escherichia coli $(16.3 \pm 0.57 \mathrm{~mm})$ by ethanol extract, followed by Shigella dysenteriae $(12.5 \pm 0.5 \mathrm{~mm})$ and a moderate inhibition of Klebsiella pneumoniae $(10 \pm 1.0 \mathrm{~mm})$ and the least activity against Salmonella typhi $(6.1 \pm 0.76 \mathrm{~mm})$. The methanol extracts showed a strong inhibitory activity against $S$. typhi $(14.8 \pm 0.76 \mathrm{~mm})$, followed by Shigella dysenteriae with a zone of inhibition $11 \pm 0.57 \mathrm{~mm}$ and a moderate inhibition against Staphylococcus aureus $(9.8 \pm 0.28 \mathrm{~mm})$ and $P$. aeruginosa $(8.8 \pm 0.76 \mathrm{~mm})$. With methanol, a minimum zone of inhibition of Rumex nervosus $(6.5 \pm 0.5 \mathrm{~mm})$ was exhibited by E. coli.

Acetone extracts of Rumex nervosus were exhibited a maximum zone of inhibition against Salmonella typhi $(11.9 \pm 0.35 \mathrm{~mm})$ followed by Staphylococcus aureus $(10.5 \pm 0.5 \mathrm{~mm})$ and minimum activity against Pseudomonas aeruginosa $(5.4 \pm 0.5 \mathrm{~mm})$. Diethyl ether extracts showed inhibitory activity against only three pathogens. The maximum inhibition was detected on Salmonella typhi $(6.2 \pm 0.68 \mathrm{~mm})$ followed by Klebsiella pneumoniae $(7.9 \pm$ $0.17 \mathrm{~mm})$ and least activity against $E$. coli $(4.8 \pm 0.76 \mathrm{~mm})$. Hexane extract didn't show any antibacterial activity against tested pathogenic bacteria. (Table .2)

Table 2: The effect of the different extracts of the leaves of Rumex nervosus against tested pathogenic bacteria (Zones of inhibition in mm; Mean \pm SD mm)

\begin{tabular}{|l|l|l|l|l|l|}
\hline \multirow{2}{*}{ Test organisms } & \multicolumn{4}{l|}{$\begin{array}{l}\text { Mean Inhibition zone of leaves extract of }{ }^{*} \text { R.nervosus in mm } \\
\text { (Mean } \pm \text { SD mm) }\end{array}$} \\
\cline { 2 - 6 } & Methanol & Ethanol & Diethyl Ether & Acetone & Hexane \\
\hline Escherichia coli & $6.5 \pm 0.5$ & $16.3 \pm 0.57$ & $4.8 \pm 0.76$ & - & - \\
\hline Salmonella typhi & $14.8 \pm 0.76$ & $6.1 \pm 0.76$ & - & $11.9 \pm 0.35$ & - \\
\hline Shigella dysenteriae & $11 \pm 0.57$ & $12.5 \pm 0.5$ & $6.2 \pm 0.68$ & $7.3 \pm 0.57$ & - \\
\hline Staphylococcus aureus & $9.8 \pm 0.28$ & $8.6 \pm 0.52$ & - & $10.5 \pm 0.5$ & - \\
\hline Pseudomonas aeruginosa & $8.8 \pm 0.76$ & $6.1 \pm 0.36$ & - & $5.4 \pm 0.5$ & - \\
\hline Klebsiella pneumoniae & $8.8 \pm 0.28$ & $10 \pm 1.0$ & $7.9 \pm 0.17$ & $5.8 \pm 0.28$ & - \\
\hline
\end{tabular}

-= implies no inhibition zone detected; * = a crude extract at concentration of $100 \mathrm{mg} / \mathrm{ml}$ was used for assay. 


\subsubsection{The antibacterial activity of Clematis simensis crude extracts}

The methanol extract of C.simensis formed a marked inhibition zone of $13.1 \pm 0.37 \mathrm{~mm}$ in diameter against $E$. coli, followed by $K$. pneumoniae $(10.9 \pm 0.3 \mathrm{~mm})$ and $S$. typhi $(9.7 \pm 0.64 \mathrm{~mm})$. The methanolic extracts exhibited the least inhibitory activity against $S$. dysenteriae and $S$. aureus with mean inhibition zone of $7.2 \pm 0.46 \mathrm{~mm}$ and $7.7 \pm 0.45 \mathrm{~mm}$ respectively. The prominent zone of inhibition from the ethanol extract of C.simensis against Shigella dysenteriae was $14.4 \pm 0.45 \mathrm{~mm}$ followed by $K$. pneumoniae $(13.9 \pm 0.35 \mathrm{~mm})$, S. typhi $(12.9 \pm 0.51 \mathrm{~mm})$ and $11.5 \pm 0.51 \mathrm{~mm}$ against $E$. coli. Moderate inhibitory activity was noticed against $S$. aureus $(10 \pm 0.15 \mathrm{~mm})$ followed by $12.1 \pm 0.3 \mathrm{~mm}$ against $P$. aeruginosa and a moderate activity of $8 \pm 0.2 \mathrm{~mm}$ against $S$. dysenteriae and $7.9 \pm 0.35 \mathrm{~mm}$ against $K$. pneumoniae and minimum inhibitory activity against $E$. coli with a zone size of $5.6 \pm 0.52 \mathrm{~mm}$. Acetone extract of C.simensis inhibited $S$. aureus with a highest zone of inhibition $11.9 \pm 0.25 \mathrm{~mm}$ and minimal inhibition was $6.8 \pm 0.2 \mathrm{~mm}$ and $5.7 \pm 0.32 \mathrm{~mm}$ against $S$. dysenteriae and $P$. aeruginosa. No good antibacterial activity was excreted by the Hexane extracts (Table 3 ).

Table 3: The effect of the different extracts of the leaves of Clematis simensis tested pathogenic bacteria (Zones of inhibition; Mean \pm SD mm)

\begin{tabular}{|l|l|l|l|l|l|}
\hline \multirow{2}{*}{ Test Organisms } & \multicolumn{4}{l|}{$\begin{array}{l}\text { Mean Inhibition zone of leaves extract }{ }^{*} \text { Clematis simensis } \\
\text { (Mean } \pm \text { SD mm) }\end{array}$} \\
\cline { 2 - 6 } & Methanol & Ethanol & D/ Ether & Acetone & Hexane \\
\hline Escherichia coli & $13.1 \pm 0.37$ & $11.5 \pm 0.51$ & $5.6 \pm 0.52$ & - & - \\
\hline Salmonella typhi & $9.7 \pm 0.64$ & $12.9 \pm 0.36$ & $6.2 \pm 0.62$ & - & $3.7 \pm 0.26$ \\
\hline Shigella dysenteriae & $7.2 \pm 0.46$ & $14.4 \pm 0.45$ & $8 \pm 0.2$ & $6.8 \pm 0.2$ & - \\
\hline Staphylococcus aureus & $7.7 \pm 0.45$ & $10 \pm 0.15$ & - & $11.9 \pm 0.25$ & - \\
\hline Pseudomonas aeruginosa & - & $8.5 \pm 0.55$ & $12.1 \pm 0.32$ & $5.7 \pm 0.32$ & - \\
\hline Klebsiella pneumoniae & $10.9 \pm 0.3$ & $13.9 \pm 0.35$ & $7.9 \pm 0.35$ & $6 \pm 0.2$ & - \\
\hline
\end{tabular}

-= implies no inhibition zone detected; *= a crude extract of at concentration of $100 \mathrm{mg} / \mathrm{ml}$ was used for assay. 3.1.3 Inhibitory Zones of test pathogens with Standard Antibiotics (Positive control)

Four dissimilar antibiotics, Ciprofloxin, Tetracyclin, Kanamycin and Chloramphenical were used as standard and as positive control for the testing of antibacterial activity of six different human pathogens. Ciprofloxin displayed maximum zone of inhibition ranging from 20-35 against all pathogens; Kanamycin exhibited average zone of inhibition $20 \mathrm{~mm}$, Tetracycline exhibited ranging from $8-20 \mathrm{~mm}$ and Chlomphenicol showed least inhibition against all test pathogens.

Table 4: The inhibition zone of antibiotics against human pathogens

\begin{tabular}{|l|l|l|l|l|}
\hline \multirow{2}{*}{ Test organisms } & Zone of inhibition in & \multicolumn{2}{l|}{} \\
\cline { 2 - 5 } & Ciprofloxin & Kanamycin & Tetracycline & Chlromphenicol \\
\hline Escherichia coli & 30 & 20 & 15 & 10 \\
\hline Salmonella typhi & 35 & 20 & 15 & 10 \\
\hline Shigella dysenteriae & 32 & 20 & 13 & 10 \\
\hline Staphylococcus aureus & 31 & 20 & 10 & 5 \\
\hline Pseudomonas aeruginosa & 30 & 15 & 8 & 5 \\
\hline Klebsiella pneumonia & 20 & 15 & 20 & 11 \\
\hline
\end{tabular}

\subsection{Minimum Inhibitory Concentration of Plant Extracts (MIC)}

The Minimum Inhibitory Concentration assay was employed to evaluate the effectiveness of the plant extracts to inhibit the growth of bacterial tested microorganisms. The extracts of the two medicinal plants were exposed to the concentrations ranged from $0.78 \mathrm{mg} / \mathrm{ml}$ to $100 \mathrm{mg} / \mathrm{ml}$. In the antibacterial activity tested, five different solvents were used for their in vitro antibacterial tested among which only best three solvents methanol, ethanol and acetone had selected for MIC test.

3.2.1. Minimum Inhibitory Concentration (MIC) of Rumex nervosus leaf extracts against tested pathogenic bacteria (in $\mathbf{m g} / \mathbf{m l}$ )

The methanol extract of Rumex nervosus exhibited the lowest MIC at 3.12 $\mathrm{mg} / \mathrm{ml}$ against E. coli and $S$. dysenteriae followed by $S$. typhi and Pseudomonas aeruginosa at a concentration of $6.25 \mathrm{mg} / \mathrm{ml}$. The ethanol extract exhibited MIC at $3.12 \mathrm{mg} / \mathrm{ml}$ concentration against $S$. dysenteriae and $K$. pneumoniae and at concentration of $6.25 \mathrm{mg} / \mathrm{ml}$ against $E$. coli. The ethanol extract also displayed its MIC at concentration of 12.5 $\mathrm{mg} / \mathrm{ml}$ against $S$. typhi and $S$. aureus. The MIC of acetone extract of Rumex nervosus was $6.25 \mathrm{mg} / \mathrm{ml}$ against the E. coli and $S$. typhi followed by $S$. dysenteriae at $25 \mathrm{mg} / \mathrm{ml}$ and $S$. aureus at $50 \mathrm{mg} / \mathrm{ml}$ (Table.5).

3.2.2. Minimum Inhibitory Concentration (MIC) of Clematis simensis leaf extracts against tested pathogenic bacteria in $\mathrm{mg} / \mathrm{ml}$

The methanol extract of Clematis simensis showed MIC activity at $6.25 \mathrm{mg} / \mathrm{ml}$ concentration against $E$. coli and $S$. typhi followed by $S$. dysenteriae and K. pneumoniae at $12.5 \mathrm{mg} / \mathrm{ml}$ concentration. The ethanol extracts showed 
strong MIC activity at $1.56 \mathrm{mg} / \mathrm{ml}$ against $S$. dysenteriae and against $S$. typhi at $6.25 \mathrm{mg} / \mathrm{ml}$ concentration followed by $S$. aureus and Pseudomonas aeruginosa at $12.5 \mathrm{mg} / \mathrm{ml}$. The acetone extract of Clematis simensis exhibited a MIC at $12.5 \mathrm{mg} / \mathrm{ml}$ against $S$. dysenteriae followed by $S$. aureus at $25 \mathrm{mg} / \mathrm{ml}$ and at $50 \mathrm{mg} / \mathrm{ml}$ against P. aerugenosa and K. pneumoniae (Table 6).

Table 5: Minimum Inhibitory Concentration (MIC) of Rumex nervosus leaf extracts against bacterial tested microorganism in $\mathrm{mg} / \mathrm{ml}$

\begin{tabular}{|c|c|c|c|c|c|c|c|}
\hline $\begin{array}{l}\text { Rumex } \\
\text { nervosus }\end{array}$ & $\begin{array}{l}\text { Conc. } \\
\mathrm{mg} / \mathrm{ml}\end{array}$ & $\begin{array}{l}\text { Escherichia } \\
\text { coli }\end{array}$ & $\begin{array}{l}\text { Salmonella } \\
\text { typhi }\end{array}$ & $\begin{array}{l}\text { Shigella } \\
\text { dysenteriae }\end{array}$ & $\begin{array}{l}\text { Staphylococcus } \\
\text { aureus }\end{array}$ & $\begin{array}{l}\text { Pseudomonas } \\
\text { aeruginosa }\end{array}$ & $\begin{array}{l}\text { Klebsiella } \\
\text { pneumoniae }\end{array}$ \\
\hline \multirow{6}{*}{ Methanol } & 1.56 & - & - & - & - & - & - \\
\hline & 3.12 & $* *$ & - & $* *$ & - & - & - \\
\hline & 6.25 & + & $* *$ & + & - & $* *$ & - \\
\hline & 12.5 & + & + & + & - & + & - \\
\hline & 25 & + & + & + & $* *$ & + & - \\
\hline & 50 & + & + & + & + & + & - \\
\hline \multirow{6}{*}{ Ethanol } & 1.56 & - & - & - & - & - & - \\
\hline & 3.12 & - & - & $* *$ & - & - & $* *$ \\
\hline & 6.25 & $* *$ & - & + & - & - & + \\
\hline & 12.5 & + & $* *$ & + & $* *$ & - & + \\
\hline & 25 & + & + & + & + & & + \\
\hline & 50 & + & + & + & + & $* *$ & + \\
\hline \multirow{6}{*}{ Acetone } & 1.56 & - & - & - & - & - & - \\
\hline & 3.12 & - & - & - & - & - & - \\
\hline & 6.25 & $* *$ & $* *$ & - & - & - & - \\
\hline & 12.5 & + & + & - & - & - & - \\
\hline & 25 & + & + & $* *$ & - & - & - \\
\hline & 50 & + & + & + & $* *$ & - & - \\
\hline
\end{tabular}

$* *=$ Minimum Inhibitory concentration, $+=$ Positive inhibition observed, $-=$ No activities

Table 6: Minimum Inhibitory Concentration (MIC) of Clematis simensis leaf extracts against bacterial tested microorganism in $\mathrm{mg} / \mathrm{ml}$

\begin{tabular}{|c|c|c|c|c|c|c|c|}
\hline $\begin{array}{l}\text { Clematis } \\
\text { simensis }\end{array}$ & $\begin{array}{l}\text { Con } \\
\mathrm{mg} / \\
\mathrm{ml}\end{array}$ & $\begin{array}{l}\text { Escherichia } \\
\text { coli }\end{array}$ & $\begin{array}{l}\text { Salmonella } \\
\text { typhi }\end{array}$ & $\begin{array}{l}\text { Shigella } \\
\text { dysenteriae }\end{array}$ & $\begin{array}{l}\text { Staphylococcus } \\
\text { aureus }\end{array}$ & $\begin{array}{l}\text { Pseudomonas } \\
\text { aeruginosa }\end{array}$ & $\begin{array}{l}\text { Klebsiella } \\
\text { pneumoniae }\end{array}$ \\
\hline \multirow{6}{*}{ Methanol } & 1.56 & - & - & - & - & - & - \\
\hline & 3.12 & - & - & - & - & - & - \\
\hline & 6.25 & $* *$ & $* *$ & - & - & - & - \\
\hline & 12.5 & + & + & $* *$ & - & - & $* *$ \\
\hline & 25 & + & + & + & - & - & + \\
\hline & 50 & + & + & + & $* *$ & - & + \\
\hline \multirow{6}{*}{ Ethanol } & 1.56 & - & - & $* *$ & - & - & - \\
\hline & 3.12 & - & - & + & - & - & - \\
\hline & 6.25 & - & $* *$ & + & - & - & - \\
\hline & 12.5 & $* *$ & + & + & - & - & $* *$ \\
\hline & 25 & + & + & + & $* *$ & $* *$ & + \\
\hline & 50 & + & + & + & + & + & + \\
\hline \multirow{6}{*}{ Acetone } & 1.56 & - & - & - & - & - & - \\
\hline & 3.12 & - & - & - & - & - & - \\
\hline & 6.25 & - & - & - & - & - & - \\
\hline & 12.5 & - & - & $* *$ & - & - & - \\
\hline & 25 & - & - & + & $* *$ & - & - \\
\hline & 50 & - & - & + & + & $* *$ & $* *$ \\
\hline
\end{tabular}

$* *=$ Minimum Inhibitory concentration, $+=$ Positive inhibition observed, $-=$ No activities (bacterial growth observed)

\section{Discussions}

Ethno botanical investigations have been found to offer significant evidences in the identification and development of traditionally used therapeutic florae into modern drugs. Involvement of the field has also reflected in the current study. The first step towards this goal was the in vitro antibacterial activity assay (Samy 
and Ignacimuthu, 2000). Many reports were available on the antiviral, antibacterial, antifungal, anthelminthic, and anti-inflammatory properties of plants (Palombo and Semple, 2001; Kumarasamy et al., 2002).

In the present study, Rumex nervosus and Clematis simensis was extracted by used different solvents such as methanol, diethyl ether, ethanol, acetone and hexane. The results of current study were an indication of such understandings. The yield of the extract that was obtained by different solvents considerably differs in two of the medicinal plants (Table 1).

In the present study, among the solvents used to extract the biologically active substances from two medicinal plants, ethanol and methanol were the best solvents, followed by acetone and least by diethyl ether and hexane (Table 2 to 5). This specified that the extraction of medicinal plants with different solvents may produce different in vitro inhibitory result which based on the potential of the solvents used to extract the biologically active constituents (George et al., 2010). The methanol and ethanol leaf extracts of Rumex nervosus showed significant antibacterial activity against most of bacterial human pathogens evaluated in the present study. The highest antibacterial activity exhibited was against $E$. coli $(16.3 \pm 0.57 \mathrm{~mm})$ by ethanol extract, followed by $S$. dysentriae $(12.5 \pm 0.5 \mathrm{~mm})$ and a moderate inhibition against $K$. pneumoniae $(10 \pm 1.0 \mathrm{~mm})$. In the present study, the methanol extract exhibited the second with inhibition zone of $14.8 \pm 0.76 \mathrm{~mm}$ against $S$. typhi, followed by $S$. dysentriae with a zone of inhibition of $11 \pm 0.57 \mathrm{~mm}$. A different study reported that the antibacterial activity of the methanolic extracts of Rumex nervosus leaves against Escherichia coli, Pseudomonas aeruginosa, Staphylococcus aureus, Streptococcus mutans and Candida albicans, with zones of inhibition of 38, 36, 15, 38 and $32 \mathrm{~mm}$, respectively (Mariam et al.,1993).

Pavithra and co-workers (2011) reported that the methanol extracts of Mollugo cerviana inhibited the growth of $S$. aureus and $E$. coli with zones of $7.33 \pm 0.57 \mathrm{~mm}$ and $11 \pm 1 \mathrm{~mm}$, respectively while chloroform extracts were ineffective against these bacterial strains. Current study showed that the methanolic extract of Rumex nervosus to have a strong inhibitory activity against tested pathogens which were in concordance with other studies. The decrease of antibacterial activity of Rumex nervosus against tested pathogens in the current study may be attributed to the difference in the initial plant extract used and extraction method used the difference in the strains of tested pathogens or due to unexplained reasons.

The acetone extracts of Rumex nervosus exhibited the maximum zone of inhibition against $S$. typhi $(11.9 \pm 0.35 \mathrm{~mm})$ followed by Staphylococcus aureus $(10.5 \pm 0.5 \mathrm{~mm})$ and minimum activity against $P$. aeruginosa $(5.4 \pm 0.5 \mathrm{~mm})$. Related investigations have reported where acetone extracts showed a marked inhibitory effect on the growth of pathogenic bacteria (Abdullahi et al., 2010). The methanol and Ethanol extract of Rumex nervosus exhibited the lowest MIC at $3.21 \mathrm{mg} / \mathrm{ml}$ concentration against Escherichia coli and Shigella dysentriae and K. pneumoniae. The result of the present study showed that the plant extracts of Clematis simensis exhibited antibacterial activity against some of the common pathogenic bacteria. The prominent zone of inhibition from the ethanol extract of Clematis simensis against $S$. dysenteriae was $14.4 \pm 0.45 \mathrm{~mm}$ and against $K$. pneumoniae was $13.9 \pm 0.35 \mathrm{~mm}$ followed by Salmonella typhi $12.9 \pm 0.51 \mathrm{~mm}$. Previous study showed that ethanolic extract of Clematis simensis exhibited a highest zone of inhibition $(28.33 \mathrm{~mm})$ against $S$. aureus with $\mathrm{MIC} 12.5 \mu \mathrm{g} / \mathrm{ml}$ (Mariam et al., 1993) a result higher than the size of inhibition zone in current study. The results of this study showed that the extracts from Clematis simensis was found to have significant antibacterial activity against both the selected Gram positive and Gram negative bacteria.

The methanol extract of Clematis simensis produced a pronounced inhibition zone of $13.1 \pm 0.37 \mathrm{~mm}$ against $E$. coli, followed by $K$. pneumoniae with a zone of inhibition of $10.9 \pm 0.3 \mathrm{~mm}$ and $S$. typhi $9.7 \pm 0.64 \mathrm{~mm}$. In current study, the result clearly showed that this plant was effective against E.coli. The possible explanation for this difference in inhibitory activity might be the ecological difference on their distribution plants which might have contributed to variations in the concentration of the active ingredients. The methanol extract of Clematis simensis showed MIC activity at $6.25 \mathrm{mg} / \mathrm{ml}$ concentration against E. coli and $S$. typhi which was supported by work of (Mariam et al.,1993) where the minimum inhibitory concentration (MIC) of isolated compounds from Clematis simensis against $S$. aureus, E. faecalis, E. coli and P. aeruginosa was found to be varied from $16 \mu \mathrm{g} / \mathrm{ml}$ to more than $250 \mu \mathrm{g} / \mathrm{ml}$. Ethanol extract showed a very minimal MIC of $1.56 \mathrm{mg} / \mathrm{ml}$ against $S$. dysenteriae and $S$. typhi which was strongly supported by the results of Tegenu Gelana (2011) where the Acetone and ethyl acetate extracts of the leaves of $Z$. scabra showed best activity against $S$. aureus exhibited an $\mathrm{MIC}$ of $1.56 \mathrm{mg} / \mathrm{ml}$ and $0.781 \mathrm{mg} / \mathrm{ml}$ respectively. The least inhibition zone was observed for hexane extract against Salmonella typhi according to Tsuchiya and coll. (1996).

\section{Conclusion}

From the above results it could be determined that the crude extracts of the two plants especially the ethanol and methanol revealed the fact that they have higher potential to produce broad spectral antibacterial activity with minimal concentration against a wide range of human pathogens. The extracts were good in inhibited Escherichia coli, Salmonella typhi, Shigella dysenteriae, P. aeruginosa and in some instances K. pneumoniae. The results of this study provided an insight into the antimicrobial properties of the extracts of Clematis simensis 
and Rumex nervosus. As well as it formed an opportunity for selection of bioactive extracts for initial fractionation and further studies of these two medicinal plants in the antibacterial assays. This in vitro study demonstrated that these two folklore medicinal plants have good potential. This study gives a suggestion of the efficacy of the plants acquired from the traditional healers. The results of study initiate basis for further studies of the powerful plants so as to segregate the compounds responsible for the antimicrobial activity. Numerous modern drugs were extracted from traditional therapeutic floras through the use of plant material succeeding the ethno botanical leads from indigenous cures used by traditional remedial systems.

\section{Competing Interests}

The authors declare that they have no competing interests.

\section{Acknowledgments}

The authors would like to thanks the Madda Walabu University for providing the facilities to work and Ethiopian Public Health Institute (EPHI) for support standard pathogen isolation and National Herbarium in Addis Ababa University for taxonomic plants identified and authenticated.

\section{References}

Abdullahi, M.I, Iliya, I, Haruna, A.K, Sule, M.I, Musa A.M. and Abdullahi, M.S. (2010). Preliminary phytochemical and antimicrobial investigations of leaf extracts of Ochna schweinfurthiana (Ochnaceae). Afr. J. Pharm. Pharmacol., 4: 083-086.

Addis, G, Abebe, D, and Urga, K. (2001). A survey of traditional medicinal plants in Shirka district, Arsi zone, Ethiopia. Ethiop. Pharm. J.19: 30-47.

Agatemor, C. (2009). Antimicrobial activity of aqueous and ethanol extracts of nine Nigerian spices against four food borne bacteria. Elec J Environ Agric food chem., 8(3): 195-200.

Amani, S, Isla, M.I. Vattuone, M, Poch, M, Cudmani, N, and Sampietro, A. (1998). Antimicrobial activities in some Argentine medicinal plants. Acta Horticulture, 501: 115-122

Bauer, A.W, Kirby, W.M.M, Sherris J,C, Turk, M. (1966). Antibiotic susceptiblity testing by a standard single disc diffusion method. AM. J.Clin. Pathol.45.493-496.

Borkotoky R, Kalita MP, Barooah M, Bora SS, Goswami C. (2013).Evaluation and screening of antimicrobial activity of some important medicinal plants of Assam. IJOART. 2(4):132-9.

Cos, P, Hermans, N, De Bruyne, T, Apers, S, Sindambiwe, J. B, Vanden Berghe, D, Pieters, L, Vlietinck, A. J.(2002).Further evaluation of Rwandan medicinal plant extracts for their antimicrobial and antiviral activities. J. Ethnopharmacol. 79: 155-63.

Costa , E.S, Hiruma-Lima , C.A, Lima, E.O, Sucupira , G.C, Bertolin, A.O, Lolis , S.F, Andrade, F.D.P, Vilegas, W. and Souza-Brito ,A.R.M. (2008). Antimicrobial activity of some medicinal plants of the Cerrado, Brazil. Phytotherapy Research. 22: 705-707.

Dean, D.A, and Burchard, K.W. (1996). Fungal infection in surgical patients. American Journal of Surgery. 171: 374-382.

Desta, B, (1993) .Ethiopian traditional herbal drugs. Part II: Antimicrobial activity of 63 medicinal plants. J. Ethnopharmk2acol. 39:129-39.

Doughari, J.H. (2006). Antimicrobial activity of Tamarindus indica Linn. Tropical Journal of Pharmaceutical Research 5: 597-603.

Edwards, S, Tadesse, M, Demissew, S. and Hedberg, 1. (2000) .Flora of Ethiopia and Eritrea, The National Herbarium, Addis Ababa, 2 (1), pp 21.

Evans, C.E, Banso , A. and Samuel,O.A . (2002). Efficacy of some nupe medicinal plants against Salmonella typhi: an in vitro study. Journal of Ethnopharmacology 80: 2124.

Gedif, T. and Hahn H. (2001) .Traditional treatment of skin disorders in Butajira, South-central Ethiopia. Ethiop. Pharm. J, 19: 48-56.

George, F.O.A, Ephraim, R.N, Obasa, S.O, and Bankole, M.O. (2010). Antimicrobial properties of some plant extracts on organisms associated with fish spoilage.University of Agriculture, Abeokuta (UNAAB) Nigeria..

Gonzalez, C.E, Venzon, D, Lee, S, Mueller, B.U, Pizzo, P.A. and Walsh, T.J. (1996). Risk factors for fungemia in children infected with human immunodeficiency virus: a case-control study. Clinical Infectious Diseases. 23: 515-521.

Haniyeh, K, Seyyed, M, Seyyed, N. and Hussein, M. (2010). Preliminary study on the antibacterial activity of some medicinal plants of Khuzestan (Iran). Asian Pacific Journal of Tropical Medicine 3(3): 180-184.

Indu, M.N, Hatha, A.A.M, Abirosh, C, Harsha, U. and Vivekanandan, G. (2006). Antimicrobial Activity of Some of the South-Indian Spices against Serotypes of Escherichia coli, Salmonella, Listeria monocytogenes and Aeromonas hydrophila. Brazilian Journal of Microbiology. 37:153-158. 
Iwu, M. M. (1993). Handbook of African Medicinal Plants, CRC Press, Boca Raton, pp 1- 7, 57.

Kakwaro, J. O,( 1976) .Medicinal plants of East Africa, East African Literature Bureau, Kampala, pp 82-3, 114, 181.

Kumaraswamy, Y, P.J. Cox, M. Jaspars, L. Naharand,S. and Sarker,D. (2002). Screening seeds of Scottish plants for antibacterial activity. J. Ethnopharmacol., 83:73-77.

Lulekal, E, Kelbessa, E, Bekele, T. and Yineger, H. (2008). An ethnobotanical study of medicinal plants in Mana Angetu District, southeastern Ethiopia. J Ethnobiol Ethnomed. 4:1-10.

Marchese, A. and Shito, G.C. (2001). Resistance patterns of lower respiratory tract pathogens in Europe. International Journal of Antimicrobial Agents 16: 25-29.

Madhu B. K, Merih T, and Robiel E, (2014). Phytochemical screening and antibacterial activity of two common terresterial medicinal plants Ruta chalepensis and Rumex nervosus: Bali Medical Journal, Bali Med. J. 3(3): $116-121$

Mariam TG, Murthy PN, Ranganathan P, Hymete A, Daka K. (1993). Antimicrobial screening of Rumex abyssinicus and Rumex nervosus. Eastern Pharm. 36(33): 131-133.

Marjorie, M.C. (1999).Plant products as antimicrobial agents. Clinical Microbiology. Reviews, American Society for Microbiology. Department of Microbiology, Miami University, Oxford, OH, USA 12: 564-582.

Mesfin, F, Demissew, S. and Teklehaymanot, T. (2009). An ethnobotanical study of medicinal plants in Wona Woreda, SNNPR, Ethiopia. J Ethnobiol Ethnomed. 5:28.

Mulu A, Moges F, Tessema B, Kassu A. Pattern and multiple drug resistance of bacterial pathogens isolated from wound infection at University of Gondar Teaching Hospital, Northwest Ethiopia. Ethiop Med J. 2006; 44(2):125-31.PubMedGoogle Scholar

Nair, R. and Chanda, S. (2006). Activity of some medicinal plants against certain pathogenic bacterial strains. Indian Journal of Pharmacology 38: 142-144.

Olivier C, Williams-Jones B, Doize B, Ozdemir V. Containing global antibiotic resistance: ethical drug promotion in the developing world. In: Sosa A et al., editors. Antibiotic resistance in developing countries. New York: Springer; 2010. p. 505-24.View ArticleGoogle Scholar

Palombo, E.A. and Sampled, S.J. (2001). Antibacterial activity of traditional medicinal plants. $J$. Ethnopharmacol., 77: 151-157.

Samy, R.P. and Ignacimuthu, S.(2000). Antibacterial activity of some folklore medicinal plants used by tribals in Western Ghats in India. J. Ethnopharmacol., 69: 63-71.

Singh, A. (2007). Herbal medicine-dream unresolved. Pharmacognosy Reviews 2: 375-376.

Tadeg, H, Mohammed, E, Asres, K. and Gebre-Mariam, T. (2005). Antimicrobial activities of some selected traditional Ethiopian medicinal plants used in the treatment of skin disorders. $J$ Ethnopharmacol. 100:168175.

Tegenu gelanaa, (2011). Antimicrobial activity of solvent-extracts of Cucumis ficifolius and Zehneria scabra on some test microorganisms. M.sc thesis Addis Ababa.

Tsuchiya, H, Sato, M, Miyazaki, T, Fujiwara, S, Tanigaki, S, Ohyama, M, Tanaka, T. and Iinuma, M. (1996). Comparative study on the antibacterial activity of phytochemical flavanones against methicillin resistant Staphylococcus aureus. J. Ethnopharmacol., 50: 27-34.

Wegiera M, Smolarz DH,Kocka BA,(2012). Rumex L. species induce apoptosis in 1301, EOL-1 and H-9 cell lines; Acta Poloniae Pharmaceutica ñ Drug Research, 69(3):487 - 499.

WHO, (2003). Traditional medicine and modern health care: progress report by the director general. Geneva: World Health Organization. 